\title{
Perancangan Cerita, Boneka Karakter dan Environment untuk Serial Teater Boneka "Tangkupet" dengan Mengangkat Unsur Identitas Lokal Indonesia
}

\author{
Muhammad Alhaq dan Senja Aprela Agustin \\ Departemen Desain Produk, Institut Teknologi Sepuluh Nopember (ITS) \\ e-mail: senja@kotasis.com
}

\begin{abstract}
Abstrak-Teater boneka merupakan salah satu budaya yang telah menjadi bagian dari kehidupan masyarakat Indonesia dan perlu terus dilestarikan. Pelestarian budaya tersebut bisa diwacanakan dengan menciptakan variasi konsep pertunjukan yang disesuaikan dengan masa sekarang, sehingga bentuk kesenian tersebut mampu bertahan di era teknologi dan memiliki daya jual di pasar seni yang terus berkembang. Saat ini mulai muncul kebutuhan teater boneka yang diciptakan kusus untuk audiens anak-anak Sekolah Dasar, namun pertunjukan tersebut masih jarang ditemui di Indonesia. Perancangan ini bertujuan untuk membuat Serial Teater Boneka "Tangkupet" untuk memenuhi kebutuhan tersebut. Pada Proses penciptaan teater boneka baru perlu mengangkat unsur identitas lokal Indenesia untuk diterapkan sebagai ide utama dalam pembuatan cerita, boneka karakter dan environment pertunjukannya. Penggunaan unsur kelokalan tersebut dapat dijadikan sebagai fitur pembeda dengan bentuk budaya negara lainnya. Perancangan ini dilakukan melalui beberapa metode yaitu studi literature, studi eksisting, interview, studi eksperimental, depth interview, expert review, prototyping, dan forum group discussion. Dari hasil riset tersebut, teater boneka Tangkupet sudah mampu memberikan sajian pertunjukan yang sesuai dengan anak-anak. Selain itu, teater boneka ini dinilai sudah dapat menampilkan unsurunsur identitas lokal Indonesia melalui cerita serial yang mengangkat pesan tentang nilai-nilai pendidikan karakter, desain boneka karakter yang mengadaptasi hewan endemik langka Indonesia, desain environment yang menampilkan bentuk bangunan rumah perkampungan lokal, dan beberapa unsur kelokalan lainnya sebagai tambahan.
\end{abstract}

Kata Kunci-Boneka Karakter, Cerita, Environment, Teater Boneka 'Tangkupet", Unsur Identitas Lokal.

\section{PENDAHULUAN}

$\mathrm{P}$ ERKEMBANGAN teater boneka di Indonesia masih cenderung tidak bergairah jika dibanding dengan perkembangan dari luar negeri, padahal teater boneka merupakan salah satu bentuk seni dan budaya yang dimiliki masyarakat Indonesia. Pengembangan puppetry dalam negeri dapat diwujudkan melalui penciptaan teater-teater boneka baru dengan alternatif variasi konsep pertunjukan yang disesuaikan dengan masa sekarang, sehingga bentuk pertunjukan tersebut mampu bertahan di tengah moderinitas dan memiliki daya jual pada pasar seni yang terus berkembang. Salah satu bentuk teater boneka tersebut adalah berjenis kontemporer, yang meliputi cerita, konsep visual dan format pertunjukannya. Pada pertunjukan teater boneka sangat dimungkinkan adanya eksperimen, penggabungan

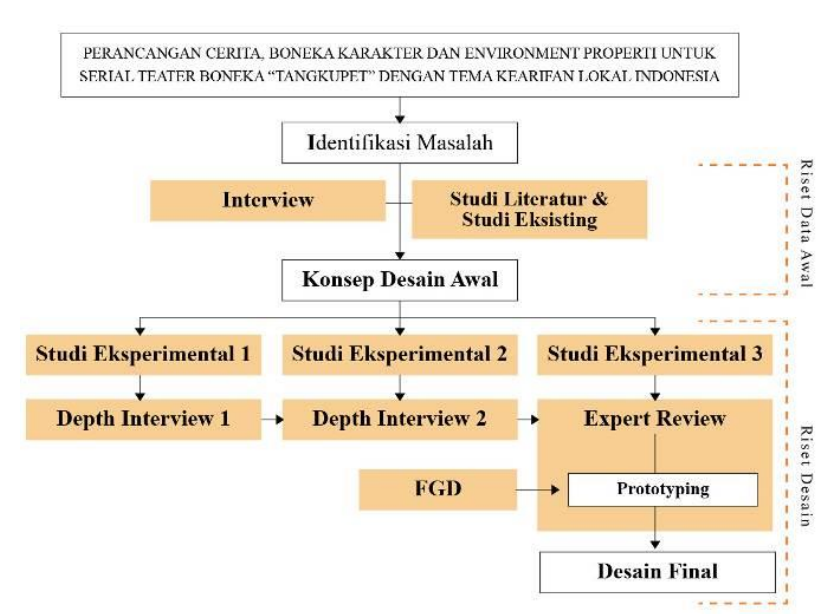

Gambar 1. Diagram Alur Riset.

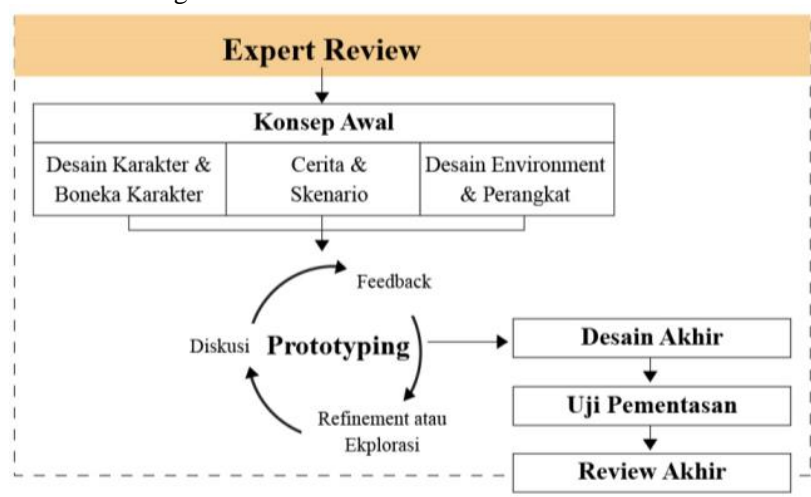

Gambar 2. Diagram Alur Expert Review pada Program PUPA Puppet Lab \#1.

beberapa jenis teater boneka sehingga menjadi sesuatu yang lebih menarik[1]. Menurut Maria Tri Sulistiyani selaku founder Papermoon, saat ini penonton Indonesia sudah sangat siap mengapresiasi pementasan teater boneka dengan segala eksperimennya, meskipun jumlah pertunjukannya masih terbatas. Ruang yang sangat baik untuk membangun penonton pertunjukan adalah dunia sekolah. Berdasarkan hasil depth interview dengan tim Papermoon Puppet theater, pada beberapa tahun terakhir banyak permintaan pementasan teater boneka untuk anak-anak di dalam negeri, namun masih jarang ditemui bentuk pertunjukan tersebut.

Maka dari itu, penelitian ini akan merancang teater boneka baru untuk anak-anak dengan nama Tangkupet. Ide dan konsep yang digunakan adalah dengan mengangkat unsur identitas lokal Indonesia. Seperti yang kita ketahui, Indonesia adalah wilayah dan bangsa yang dianugerahi oleh kekayaan dan keunikan budaya dan tradisi masyarakat yang 
Tabel 1.

Spesifikasi Cerita Episode 1-5

\begin{tabular}{lll}
\hline \hline No. Judul Episode & Nilai Pendidikan Karakter \\
\hline 1 & Sepatuku Juga Bagus & Kerja keras dan rajin menabung \\
2 & Kamu Punya bakat & Anti diskriminasi dan empati \\
3 & Makanannya Hilang: & Anti korupsi \\
4 & Hormat Merah Putih & Cinta tanah air dan semangat \\
& & kebangsaan \\
5 & Jangan Takut Gelap & Mandiri dan kreatif \\
\hline \hline
\end{tabular}

Tabel 2.

Rancangan Kebutuhan Karakter.

\begin{tabular}{ll}
\hline \hline Karakter & \multicolumn{1}{c}{ Keterangan } \\
\hline Bu Tantri & $\begin{array}{l}\text { Tokoh pendamping sebagai ibu pengasuh dan } \\
\text { penengah bagi anak-anak. Ia berperan sebagai } \\
\text { penasehat dan penyampai amanat. }\end{array}$ \\
Ulin & $\begin{array}{l}\text { Anak gajah yang hobinya melukis. Ia dikagumi } \\
\text { karena dia sangat baik dan pekerja keras. Sayangnya } \\
\text { ia cenderung pemalu dan pemurung. }\end{array}$ \\
Reka & $\begin{array}{l}\text { Anak merak hijau yang sangat centil dan cerewet. Ia } \\
\text { sangat takut hal-hal yang jelek dan jorok. Ia memiliki } \\
\text { penampilan paling menarik }\end{array}$ \\
Jawo & $\begin{array}{l}\text { Anak owa Jawa yang sehari-harinya sealu lincah. Ia } \\
\text { merupakan anak yang kurang pandai, namun suka } \\
\text { menghibur semua orang dengan sifatnya yang jenaka. }\end{array}$ \\
Saka & $\begin{array}{l}\text { Anak rusa yang tangkas dan cekatan. Walaupun ia } \\
\text { masih sangat kecil, ia berani membela kebenaran. }\end{array}$ \\
Hobinya adalah pramuka dan bersepeda. \\
Rima & $\begin{array}{l}\text { Anak harimau yang cantik tapi tomboy sekali. Ia cuek } \\
\text { dan terkesan pemarah. Ia tidak suka diremehkan } \\
\text { sebagai anak perempuan yang lemah. } \\
\text { Anak badak jawa bertubuh gempal. Ia sangat kuat dan } \\
\text { suka mengganggu teman-temannya, padahal } \\
\text { sebenarnya ia adalah anak yang sangat manja. }\end{array}$ \\
Bondel & $\begin{array}{l}\text { Anak penyu hijau yang paling pintar. Dia suka } \\
\text { membaca buku pengetahuan dan membuat penemuan- } \\
\text { penemuan menarik } \\
\text { Anak permpuan anoa yang berbadan gembul. Karena } \\
\text { ia terlalu baik, ia sering dimanfaatkan oleh teman- } \\
\text { temannya. Hobinya memasak dan bernyanyi } \\
\text { Anak julang Sulawesi yang ceria. Ia sangat cinta } \\
\text { lingkungan dan kebersihan. Namun banyak yang tidak } \\
\text { suka dengannya karena ia terlalu cerewet. }\end{array}$ \\
Bayu & \\
Gani &
\end{tabular}

beraneka ragam. Kelebihan tersebut dapat menjadi value proposition dari suatu produk kreatif. Keunikan kebiasaan, kepercayaan, gaya hidup, tutur kata, dialek, dan wujud dari arsitektur maupun tata letak ruangan di sejumlah daerah di Indonesia seakan menjadi sumber ide yang sangat kaya. Setidaknya terdapat 17 kategori budaya lokal, antara lain tatanan nilai dan gagasan, bentuk kesenian, kenegaraan, transportasi, musik, properti, bangunan, bahasa, geografis, kuliner, kostum dan lain sebagainya[2]. Sumber ide kelokalan tersebut seharusnya dapat dimanfaatkan oleh para kreator dengan memasukkannya ke dalam karya. Unsur kelokalan tersebut dapat dijadikan sebagai pembeda dengan budaya negara lain.

Mengikuti salah satu dari dua tujuan Adrian Kohler dan ketiga koleganya saat awal mendirikan Hanspring Puppet Company di Cape Town pada tahun 1981, yaitu untuk menciptakan teater boneka baru bagi anak-anak yang mencerminkan kehidupan di benua tempat mereka hidup. Mereka berusaha membuat sesuatu yang baru berdasarkan kondisi budaya lokal setempat yang berlaku[3]. Seperti pada tayangan serial animasi Upin \& Ipin yang saat ini sedang populer, mengusung cerita keseharian anak kembar yang dibalut dengan tema budaya Melayu. Upin-Ipin banyak mengangkat budaya-budaya kampung Malaysia yang dijadikan bahan cerita pada film animasinya. Selain bahasa Melayu, diangkat pula elemen-elemen budaya lainnya seperti baju adat, bentuk rumah \& lingkungan sekitar, permainan, ragam makanan \& minuman khas hingga ceritacerita rakyat yang berasal dari Malaysia[4]. Di dalam konten Upin \& Ipin juga memuat tentang penyampaian pendidikan moral dan karakter, pengajaran nilai-nilai, dan universalitas dunia anak-anak yang khas Malaysia. Demikian pula dengan film boneka Si Unyil yang memuat banyak sekali konten-konten lokal khas Nusantara yang diterapkan pada berbagai elemen. Karakter Unyil tersebut pada akhirnya didapuk sebagai salah satu karakter yang paling berpengaruh, mampu merepresentasikan wajah Indonesia melalui pesan multikulturalisme[4].

Sebuah pertunjukan teater boneka yang menarik tentu memiliki materi cerita dan artistik yang bagus dan layak untuk ditonton. Maka dari itu Teater Boneka tangkupet didesain secara menarik melalui cerita, desain boneka karakter dan environment.

\section{A. Rumusan Masalah}

"Bagaimana merancang cerita, boneka karakter dan environment dengan mengangkat unsur identitas lokal Indonesia unuk Serial Teater Boneka Tangkupet?”

\section{B. Batasan Masalah}

1. Perancangan ini membahas penerapan unsur-unsur identitas lokal Indenesia sebagai ide dasar dalam pembuatan cerita, desain boneka karakter dan desain environment untuk Serial Teater Boneka Tangkupet.

2. Target audiens dalam perancangan ini adalah anak-anak usia sekolah dasar.

\section{Maksud dan Tujuan}

1. Merancang cerita, boneka karakter dan environment yang mengangkat unsur identitas lokal indonesia untuk menciptakan teater boneka Tangkupet.

2. Memanfaatkan kekayaan budaya lokal Indonesia agar mampu menciptakan identitas yang dapat dibedakan dengan bentuk seni dan budaya dari negara lain.

3. Menciptakan teater boneka baru untuk anak-anak sebagai alternatif hiburan edukatif yang ditampilkan secara live performing di tengah kebiasaan anak yang kecanduan media digital.

\section{STUDI LITERATUR}

\section{A. Unsur Identitas Lokal Indonesia}

Tinjauan tentang unsur identitas lokal Indonesia mencakup pengertian dasar identitas lokal, manfaat, pengelompokan tema kategori beserta unsur-unsur di dalamnya dan contoh penerapan unsur tersebut pada penciptaan karya kreatif. Selain tinjauan tersebut juga dilakukan tinjauan terhadap unsur identitas kelokalan Indonesia yang dipakai sebagai ide dasar dalam perancangan ini seperti nilai-nilai pendidikan karakter, hewan langka endemik Indonesia, bangunan rumah lokal, dan bentuk 
pakaian masyarakat lokal. Seluruh informasi ini didapat dari berbagai sumber literatur seperti jurnal maupun literatur digital[2], [4].

\section{B. Teater Boneka}

Teori teater boneka yang dipakai sebagian besar mengacu buku karangan David Currel dan beberapa literatur tambahan. Hasil tinjauan teori tersebut antara lain tentang komunikasi pada teater boneka, teknik dan gaya permainan boneka, bentuk pementasan (staging), dan tahapan-tahapan dalam pembuatan teater boneka[1], [5]. Menurut David Currel, pembuatan teater boneka terdiri dari beberapa tahapan yaitu: didahului dengan melakukan riset pendahuluan; kemudian membuat konsep; menentukan jenis pertunjukan; lalu pembuatan cerita dan skenario yang bisa dilakukan bersamaan dengan pengembangan desain dan konstruksi; dilanjutkan dengan latihan olah suara dan gerak; hingga menghasilkan sebuah pertunjukan.

\section{Cerita}

Teori ini digunakan sebagai acuan dalam pembuatan cerita dan skenario, yang didalammnya mencakup teori tentang unsur-unsur pembentuk cerita, proses pembuatan cerita secara umum, pegkarakteran dalam cerita, hingga teori pembuatan naskah pertunjukan[1], [6], [7].

\section{Kriteria cerita untuk anak-anak}

Tinjauan ini digunakan untuk mencari tahu kriteria cerita yang disenangi anak-anak yang telah disesuaikan dengan kebutuhannya, terkait isi dan tema cerita, teknis penceritaan, penggunaan media dan kriteria lainnya. Hasil tinjauan ini akan diterapkan sebagai ide dalam menyusun konsep dasar perancangan ini[8], [9].

\section{E. Desain Karakter}

Teori desain karakter ini dipakai sebagai prinsip dalam perancangan karakter yang berorientasi pada bentuk boneka. Teori ini meliputi proses pembuatan karakter; studi archetype yang merupakan tipe-tipe kepribadian dan psikologis yang sangat mempengaruhi bentuk fisik karakter; dan studi antropomorfisme yang merupakan konsep penggabungan karakteristik hewan dengan manusia. Proses pembuatan karakter meliputi pengembangan secara deskriptif melalui penyusunan identitas karakter dan pengembangan secara visual dengan mengacu pada gaya gambar Stylized Cartoon, menerapkan teori basic shape, dan teori warna[10]-[12].

\section{F. Desain Boneka / Puppet}

Teori desain boneka ini digunakan sebagai panduan dalam merancang boneka karakter, meliputi prinsip-prinsip desain boneka, proporsi boneka, bentuk-bentuk boneka berdasarkan strukturnya, material beserta teknik pembuatannya, konstruksi dan sambungan dan pembuatan kostum[1].

\section{G. Desain Environment}

Tinjauan teori tentang desain environment ini meliputi prinsip dasar environment dan komponen environment. Prinsip dasar ini digunakan untuk menentukan teknik environment yang mendudukung terciptanya sebuah dunia dalam sebuah cerita. Komponen dasar penyusun environment dibagi lagi menjadi set property dan hand property[13].

\section{H. Studi Eksisting}

Studi eksisting digunkan untuk mengkaji dan mengadaptasi komparator teater boneka yang sudah ada terkait teknis penyajian pertunjukan, konsep tema, cerita dan konten yang disampaikan, desain karakter, penggayaan visual, desain boneka, dan enviroment serta propertinya. Eksisting tersebut antara lain Sesame Street, film serial boneka Si Unyil, pertunjukan teater boneka Papermoon Puppet Theatre, dan pertunjukan Wayang Kancil.

\section{METODOLOGI PENILITIAN}

\section{A. Metodologi Penelitian}

Metode pengumpulan data riset dilakukan secara kualitatif melalui dua tahapan yaitu:

1) Riset Penggalian Data Awal

Riset penggalian data awal dilakukan melalui studi literatur, studi eksisting, dan Interview. Studi literatur dan studi eksisting digunakan untuk mencari teori-teori yang dipakai sebagai panduan dan mencari hasil penelitian terdahulu sebagai dasar menentukan konten perancangan. Kemudian dilanjutkan melakukan Interview kepada Ibu Tiyas dan ibu Melati guru SD, ibu Linia guru teater anakanak, dan bapak Tobi pendongeng profesional. Dari hasil interview didapatkan karakteristik anak-anak usia SD, mendapat formulasi kriteria media yang sesuai kebutuhan anak-anak saat ini, serta mendapat tanggapan tentang perancangan ini. Dari keseluruhan hasil yang didapat pada riset ini, dihasilkan konsep desain awal sebagai dasar pengembangan elemen perancangan pada riset desain.

2) Riset Desain

a. Studi eksperimental I digunakan untuk membuat cerita melalui proses brainstorming ide cerita hingga dihasilkan rancangan cerita serial sebanyak 20 sinopsis dan salah satu sinopsisnya dibuat ke dalam bentuk skenario pertunjukan.

b. Studi eksperimen II digunakan untuk merancang konsep desain karakter dan desain environment, kemudian dilanjutkan dengan membuat eksplorasi desain untuk menghasilkan 10 desain karakter secara deskriptif dan visual lengkap dengan hubungan antar karakternya.

c. Studi eksperimental III merupakan proses pembuatan konsep boneka dan eksplorasi material hingga dihasilkan prototype awal berupa satu boneka karakter.

d. Depth interview I tentang cerita, dilakukan untuk mendiskusikan hasil sinopsis cerita dan skenario kepada Rona Mentari pendongeng profesional. Secara umum cerita yang dibuat sudah sesuai dengan kebutuhan anak-anak terkait teknis penceritaan dan konten ceritanya serta mampu memunculkan unsurunsur identitas lokal melalui penggunaan nilai pendidikan karakter sebagai pesan cerita; personaliti karakter yang mengacu sifat anak-anak lokal pada dunia nyata; dan penggunaan nama-nama karakrter yang familiar di masyarakat lokal. Dari 20 sinopsis yang telah dibuat, 5 sinopsis diantaranya telah direview dan disetujui terkait pesan nilai-nilai pendidikan karakter. 
e. Depth interview I untuk desain karakter dan environment, dilakukan untuk mendiskusikan hasil desain karakter dan desain environment yang telah dibuat kepada Risma Suherja, desainer animasi web series. Dari tahap ini didapat masukan untuk memperkuat desain karakter dan environment yang sudah dibuat dengan cara meninjau ulang proses perancangan karakter yang didukung pengaplikasian teori-teori desain karakter.

f. Expert Review tentang teater boneka, dilakukan untuk mendiskusikan kembali hasil studi eksperimental I, II dan III beserta masukan ahli pada Depth Interview I dan II kepada narasumber tim Papermoon Puppet Theatre, Maria Tri Sulistyani, Sanjaya Beni, Anton Fajri, Pambo Priyo Jati dan Iwan Efendi pada program workshop eksperimental PUPA Pupppet Lab. Di dalam program yang berlangsung selama satu bulan ini, penulis dan tim Tangkupet dibimbing langsung oleh narasumber-narasumber tersebut dalam mengembangkan projek secara keseluruhan. berbagi temuan-temuan dan pertanyaan mengenai teater boneka; mencari teknik memainkan boneka; mendiskusikan plot cerita; membahas pengembangan desain karakter dan environment; perancangan teknik boneka dan properti; menyusun narasi pertunjukan final melalui uji pementasan; hingga dihasilkan konsep desain akhir. Pada awal mengikuti program, penulis terlebih dahulu memaparkan keseluruhan konsep perancangan. Lalu penulis mendapat feedback dari hasil diskusi bersama untuk diteruskan dengan melakukan refinement sementara. Setelah refinement terselesaikan, kemudian dilanjutkan dengan melakukan testing. Dari hasil ini jika subjek desain dinilai masih belum maksimal, perlu didiskusikan kembali dan mengulangi proses sesuai skema prototyping hingga mencapai hasil yang paling baik. Di ahhir program, hasil perancangan ini dipentaskan secara langsung ke audiens anak-anak untuk mendapatkan review langsung dari target audiens dan pakar sehingga didapatkannya kriteria desain final.

g. Forum group discussion kesesuaian karya untuk anak, Forum group discussion ini merupakan salah satu agenda di dalam program PUPA Puppet Lab, dilakukan ditengah proses pembuatan prototype untuk meninjau ulang apakah hasil perancangan teater boneka yang sedang dibuat sudah sesuai dengan pememenuhan hakhak anak dan kebutuhan anak-anak. Tahap ini dilakukan bersama 25 peserta lainnya dan tim papermoon dengan dua narasumber praktisi pemerhati anak dan fasilitator dari ECCD-RC (Early Childhood Care \& Development - Resource Center) Yogyakarta, Hasanah Safriyani dan Putri Wulan.

\section{ANALISIS HASIL PENELITIAN}

\section{A. Target Audiens}

\section{1) Demografis}

Berdasarkan hasil riset, telah ditentukan target audiens yang paling optimal adalah anak-anak Sekolah Dasar kelas 1-3 dengan rentang usia 7-9 tahun. Penonton berjenis kelamin laki-laki dan perempuan. Audiens merupakan masyarakat domestik karena tujuan karya ini dibuat memang untuk masyarakat lokal dan pertunjukannya sendiri juga didominsi menggunakan Bahasa Indonesia.

2) Geografis

Target audiens yang tinggal di Surabaya dan sekitarnya, dan Yogyakarta yang mayoritas bertempat tinggal di lingkungan padat penduduk seperti perkotaan dan perkampungan, dengan lokasi yang dapat terjangkau dengan mudah.

\section{3) Psikografi}

- Suka bermain dan berinteraksi dengan teman maupun lingkungan sekitarnya.

- Memiliki rasa ingin tahu dan suka dengan hal-hal baru.

- Memiliki waktu belajar dan bermain yang cukup.

- Membutuhkan bimbingan terhadap berprilaku, emosi labil, masih perlu untuk ditunjukan bagaimana berprilaku yang sesuai dengan usianya.

\section{B. Analisis Kebutuhan Media dan Teknis Petunjukan}

Berdasarkan hasil penelitian, Serial Teater Boneka Tangkupet ini diciptakan sebagai upaya pemenuhan kebutuhan teater boneka baru untuk anak-anak. Dari hasil interview pertunjukan teater boneka ini dapat dijadikan alternatif hiburan seni lokal untuk mengalihkan kecenderungan anak-anak terhadap gadget. Pada dasarnya anak-anak mudah bosan sehingga objek-objek pada teater boneka dibuat berwujud 3D dan memiliki tampilan visual yang bagus akan dapat menarik perhatian anak. Namun selain menjadi media hiburan, teater ini juga harus memiliki manfaat edukatif salah satunya dengan mengangkat nilai pendidikan karakter sebagai pesan cerita. Teater boneka ini dirancang untuk keberlanjutan yang diimplementasikan melalui metode pentas keliling.

Mengacu pada karakteristik audiens yang sedang berada pada tahap perkembangan operasional konkret, pertunjukan ini dibuat dengan memadukan elemen visual dari boneka dan elemen verbal melalui dialog antar karakternya. Penggunaan dialog ini dimaksudkan agar anak-anak lebih mudah mengikuti jalannya cerita. Pementasan pada perncangan ini ditampilkan secara life performing karena memiliki kelebihan adanya interaksi nyata antara penonton dan penampil. Dalam konsep ini perlu didukung dengan menggunakan bentuk pangung terbuka tanpa sekat sehingga penonton merasa lebih dekat dengan penampil.

Dari penjabaran tersebut, ditentukan teknik permainan boneka yang digunakan. Teknik tersebut adalah perpaduan dari teknik Bunraku style, teknik Muppet, dan teknik Kuruma Nigyou. Membutuhkan pemain boneka khusus dan dubber yang berbeda.

\section{Analisis Konten Identitas Lokal Indonesia}

Berdasarkan analisis referensi-referensi animasi yang mengangkat unsur kelokalan sebagai ide dalam pembuatan suatu karya kreatif[4], dengan ditambah dari hasil studi literatur dan riset primer, penulis kemudian menentukan unsur-unsur apa saja yang dipakai dalam perancangan ini. Mengacu pada unsur budaya lokal setidaknya terdapat 17 kategori unsur identitas lokal Indonesia[2]. Sebagian unsurunsur yang dimuat dalam kategori-kategori budaya lokal tersebut yang penulis pakai yaitu: unsur nilai pendidikan karakter (kategori Gagasan); unsur atribut pendukung (kategori properti umum); unsur gaya bahasa dan dialek (kategori bahasa dan komunikasi); unsur bentuk bangunan 
rumah tinggal di perkampungan (kategori bangunan, struktur dan penanda); unsur hewan endemik langka Indonesia (kategori alam dan geografis); unsur karakter yang terlihat memiliki sifat masyarakat lokal (kategori orang); dan unsur pakaian masyarakat tropis (kategori kostum). Masingmasing unsur tersebut memiliki alasan yang kuat sehingga digunakan sebagai ide dalam perancangan ini.

\section{Analisis Cerita}

Penulis mengadaptasi hasil penelitian beberapa orang untuk menentukan kriteria cerita dalam perancangan ini, yang dipadukan dari hasil riset data primer yang penulis lakukan[8], [9]. Berikut adalah kriteria cerita dalam perancangan ini.

- Dibuat dalam bentuk serial dengan episode yang berbedabeda

- Cerita sangat anak-anak, dari sisi konten maupun teknis penceritaan.

- Berkonsep dunia fabel. Mengacu dari kecenderungan anak-anak yang menyukai karakter hewan yang seolaholah berperilaku seperti manusia.

- Pesan cerita berisikan nilai-nilai pendidikan karakter.

- Tema cerita tentang kehidupan keseharian yang didalamnya terdapat berbagai kegiatan.

- Di dominasi oleh karakter dengan usia anak-anak, dan jika menggunakan karakter usia dewasa perannya adalah sebagai penengah

- Memperhatikan teknik penceritaan untuk anak-anak, Menggunakan alur maju dengan konflik sederhana. yang diciptakan dari permasalahan antar teman. Menggunakan bahasa indonesia yang ringan dan mudah dipahami. Durasi cerita 20 menit. Dan hal-hal teknis lainnya.

\section{E. Desain Karakter}

- Berorientasi pada bentuk boneka.

- Karakter mengadaptasi hewan langka endemik indonesia. Hewan langka endemik ini dipilih karena memiliki ciri kusus sebagai identitas lokal yang hanya dijumpai di Indonesia.

- Membuat 10 desain karakter untuk kebutuahan cerita serial. Masing-masing karakter tersebut memiliki ciri khas yang berbeda dari sisi bentuk, warna, sifat dan latar belakangnya.

- Desain kostum menggunakan bentuk pakaian sederhana.

- Menggunakan gaya visual kartun stilasi.

- Menggunakan konsep antropomorfisme mengawinkan kararakteristik hewan dan karakteristik manusia.

- Menggunakan teori-teoi dalam perancangan karakter, seperti teori desain karakter, teori basic shape, konsep antropomorfisme, dan analisis archetype.

\section{F. Boneka Karakter}

- Membutuhkan boneka dengan dengan bentuk bentuk perpaduan dari mouth puppet dan bunraku puppet.

- Boneka berbentuk 3D berbentuk humanoid dengan ukuran 60-90 cm. Terdiri dari bagian kepala dan rongga mulut, badan, tangan dan kaki.

- Mempunyai sistem kerangka dan persendian yang baik

\section{G. Desain Environment}

- Environment dibuat menetap selama pertunjukan dan membutuhkan properti yang sedikit. Terdiri dari set property dan hand propert. Set properti berjumlah satu dengan menampilkan bentuk bangunan rumah lokal di perkampungan. Anak-anak suka dengan environment menggunakan latar tempat yang dekat dengan keseharian mereka seperti rumah, sekolah, taman, lapangan, dll.

- Ukuran real menyesuaikan dengan proporsi boneka

- Menggunakan gaya stilasi dan menampilkan kesan rustik.

- Set property bisa dibongkar pasang untuk meminimalisis ruang penyimpanan dan fleksibilitas tempat

\section{KONSEP DESAIN DAN IMPLEMENTASI}

\section{A. Konsep Desain}

Konsep dari perancangan Tangkupet yang mengangkat unsur identitas lokal indonsia sebagai tema utama adalah dengan big idea "dunia fabel vernakular". Mengacu pada ketertarikan target audiens terhadap cerita yang bertokoh binatang yang berprilaku seperti manusia, maka konsep tangkupet dibuat seolah-olah berada di dunia binatang yang kurang lebih mirip dengan dunia manusia. Dunia Tangkupet mengusung tema vernakular yang mana sangat menonjolkan unsur identitas lokal Indonesia, mulai dari bentuk bangunan environment yang mengadaptasi gaya rumah lokal, hingga penggunaan model pakaian yang dikenakan oleh tokoh bertemakan pakaian ringan dan sederhana yang disesuaikan dengan aktifitas sehari-hari masyarakat iklim tropis.

Namun dalam upaya menyampaikan unsur kelokalan tersebut, tidak melulu tentang visual saja, tetapi bisa juga melalui penggambaran citra lokal yang ditampilkan melalui penggunaan dialek kedaerahan sebagai aksen bahasa dan komunikasi dan perilaku sosial karakter-karakter yang hidup di dalam cerita. Sehingga konsep berkehidupan masyarakat Indonesia yang penuh dengan nilai-nilai bangsa dapat diterapkan ke dunia Tangkupet. Adapun identitas yang tergambar dalam dunia Tangkupet merupaan refleksi dari anak-anak nusantara.

\section{B. Cerita}

Konsep cerita "Serial Teater Boneka Tangkupet" secara keseluruhan bertema slice of life, bercerita mengenai kehidupan sehari-hari anak-anak hewan yang beraktivitas seperti manusia yang tinggal, belajar dan bermain di lingkungan "Rumah Soaka". Rumah ini adalah rumah panti asuhan yang dikelola oleh seorang ibu orangutan bernama bu Tantri. Selain sebagai penjaga rumah panti asuhan, bu Tantri ini juga berperan sebagai pengasuh anak-anak tersebut, yang memiliki latar belakang berbeda-beda sehingga mereka tinggal di panti asuhan ini.

Di dalam setiap cerita memiliki pesan untuk menanamkan nilai-nilai pendidikan karakter anak bangsa seperti kerja keras, saling menyanyangi, cinta lingkungan, bela negara, dll. Pesan moral tersebut disampaikan melalui konflik yang sederhana dengan masalah yang ditimbulkan dari tiap individu karakter dengan temannya. Cerita menggunakan 
alur maju dan bahasa yang ringan. Strategi penyampaian cerita menggunakan komunikasi sehari-hari agar mudah untuk dipahami. Menggunakan bahasa Indonesia dan beberapa karakter memiliki aksen kedaerahan yang khas. Cerita dibawakan secara menyenangkan melalui adanya jargon dan pantun

Dari hasil review pakar, terdapat 5 sinopsis cerita yang telah direview dan disetujui terkait konten dan teknisnya dapat dilihat pada Tabel 1 .

Selain dari 5 sinopsis tersebut, penulis telah mempersiapkan 15 sinopsis lainnya dengan cerita dan muatan pesan nilai pendidikan karakter yang lain. Sinopsis cerita dengan judul Sepatuku Juga Bagus dibuat dalam bentuk skenario pertunjukan untuk pementasan episode perdana. Pementasan ini yang akan diujikan kepada target audiens untuk mengetahui tngkat keberhasilan perancangan ini.

\section{A. Desain karakter}

Desain karakter ini dibuat sesuai dengan kebutuhan pada pengembangan konten cerita. Perancangan karakter tersebut mengadaptasi satwa endemik Indonesia, meliputi morfologi, fisiologi maupun latar belakang status kelangkaannya. Terdapat setidaknya 10 hewan antara lain Orangutan, Gajah Sumatera, Rusa Bawean, Harimau Sumatera, Owa Jawa, Merak Jawa, Badak Jawa, Penyu Hijau, Julang Kalimantan dan Anoa. Hewan tersebut dipilih sebagai daya tarik tersendiri untuk membawa konteks kelokalan Indonesia dengan menumbuhkan kecintaan terhadap keanekaragaman hayati milik bangsa.

Dimulainya tahap ini berawal dari inisiatif dan ide yang muncul untuk menelusuri jenis hewan yang termasuk dalam bagian paling "terancam punah", terkenal sangat populer di masyarakat, atau yang memiliki latar belakang paling menarik diantara yang lainnya.

Karakter-karakter ini diberi nama dengan nama-nama lokal yang umumnya mudah dikenali oleh masyarakat Indonesia dapat dilihat pada Tabel 2.

Perancangan karakter dimulai dari mencari referensi desain dan melakukan eksplorasi visual untuk menemukan gaya gambar. Pada perancangan ini, karakter menggunakan gaya kartun stilasi agar bisa dimodifikasi ke dalam bentukan hunanoid dengan menonjolkan beberapa ciri khas namun karakteristik dari hewan aslinya masih muncul. Lalu dilanjutkan dengan mengembangkan konsep karakter secara deskripsi. Di dalamnya terdapat unsur pembentuk karakter yang akan dibagi menjadi beberapa bagian meliputi informasi dasar, fitur pembeda, karakteristik sosial, dan kaakter emosional. Setelah pemuatan konsep secara deskripsi selesai, mulai dilakukan analisis archetype pada referensi karakter yang sudah ada. Dari hasil analisis tersebut didapatkan bagaimana karakter dengan tipe archetype tersebut dimunculkan dalam bentuk visual, terkait proporsi, wajah, dan pakaian dan atributnya.

Proses pengembangan visual dimulai dengan ekplorasi yang mempelajari karakteristik hewan hingga menghasilkan alternatif desain dengan gaya gambar yang dimaksud. Berikut adalah salah satu contoh pengembangan visual dari karakter bu tantri seperti pada Gambar $3-4$.

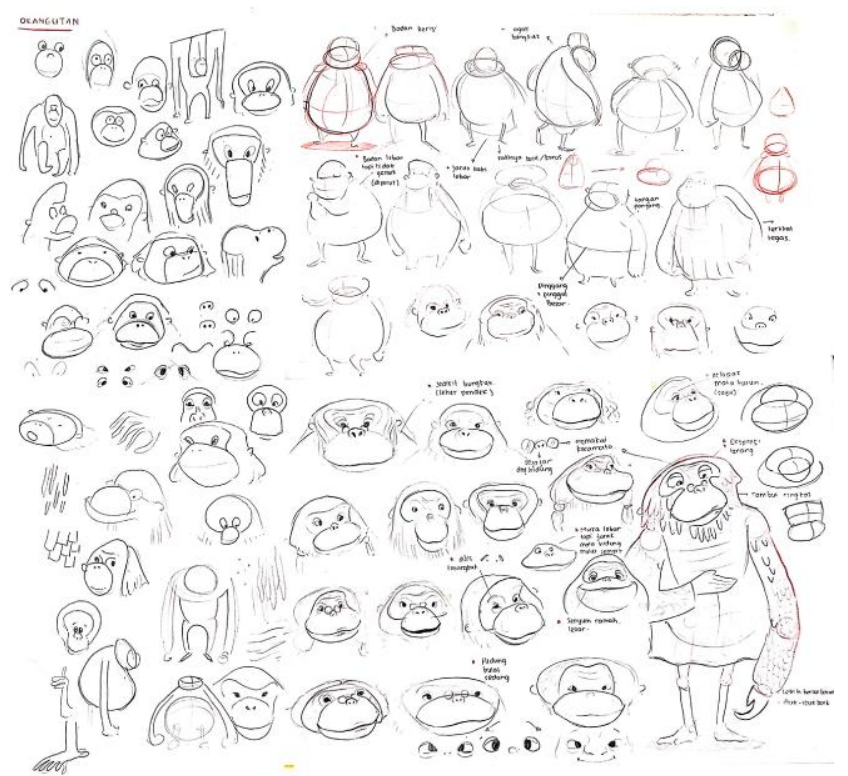

Gambar 3. Eksplorasi desain karakter bu tantri.

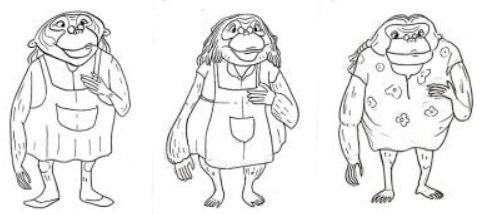

Gambar 4. Alternatif desain karakter bu tantri.
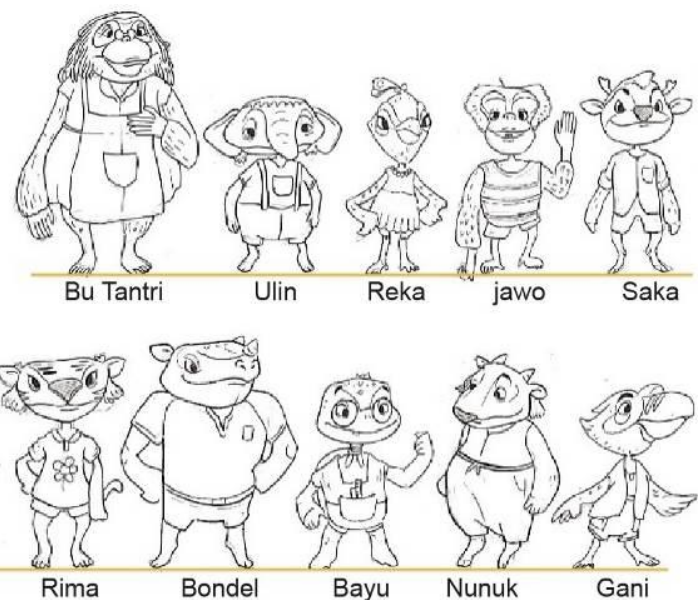

Gambar 5. Desain final seluruh karakter.

Dari hasil alternatif sketsa yang telah dibuat, penulis telah memilih salah satu dari masing-masing alternatif tersebut yang dianggap paling merepresentasikan konsep karakter. Berikut adalah perbandingan ukuran proporsi antar karakter terpilih seperti pada Gambar 5.

Kostum menggunakan pakaian yang sesuai dengan kebiasaan berpakaian sehari-hari masyarakat Indonesia pada umumnya. Contohnya seperti kaos oblong, celana pendek, baju daster dengan bahan kain yang mudah menyerap keringat, kemeja terbuka yang ringan dipakai, dan lain sebagainya.

\section{B. Desain boneka}

Desain boneka merupakan perpaduan dari bentuk mouth puppet untuk kebutuhan berdialog dan bentuk bunraku puppet unuk memungkinkan melakukan banyak gerakan. Boneka dirancang dengan menggunakan sistem kerangka dan persendian yang baik untuk mendukung konsep 

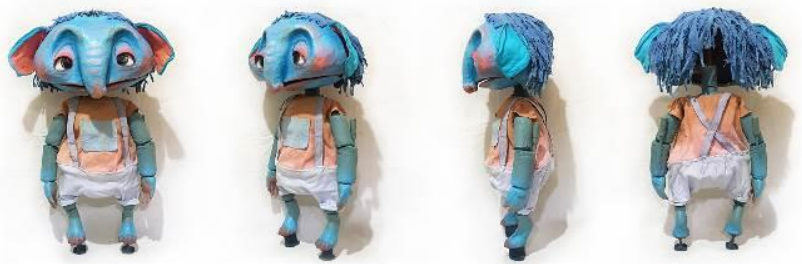

Gambar 6. Boneka karakter Ulin.
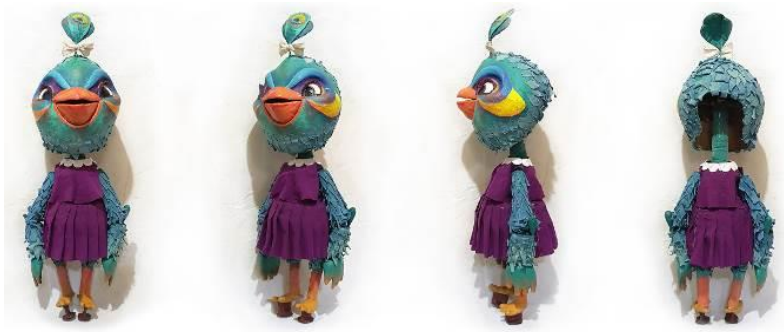

Gambar 7. Boneka karakter Reka.
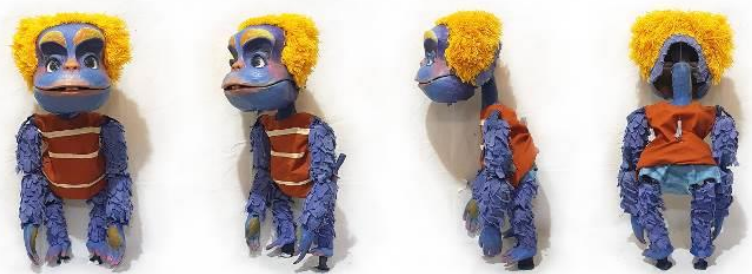

Gambar 8. Boneka karakter Jawo.
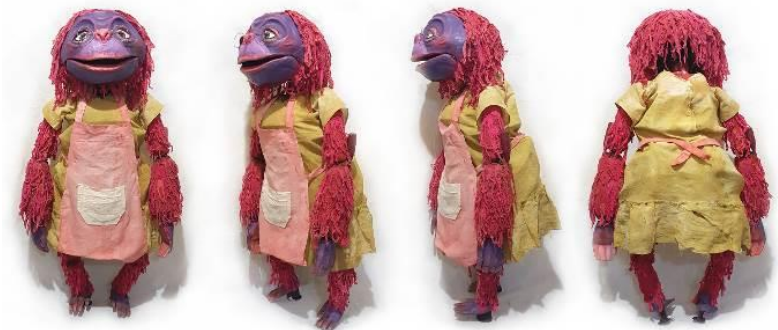

Gambar 9. Boneka karakter Bu Tantri.

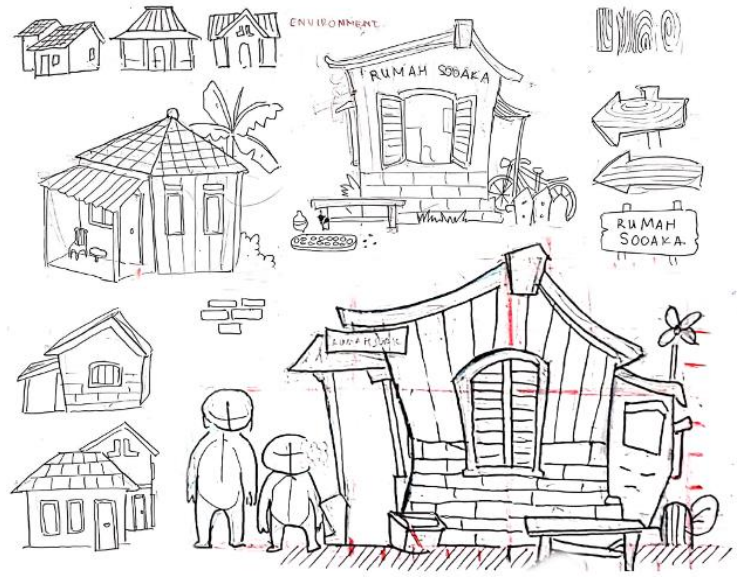

Gambar 10. Eksplorasi Environmet.

permainan. Material yang digunakan untuk membuat bentuk dasar boneka adalah rotan, busa, kain dan kertas dengan teknik perakitan modeling, sculpting dan papermache.

Pada perancangan ini, boneka yang dibuat untuk kebutuhan skenario episode pertama sebanyak 4 karakter, antara lain karakter Ulin, Reka, Jawo dan bu Tantri seperti pada Gambar 6 - 9.

Boneka dibuat dengan visual yang detail dengan konsep warna full color agar berkesan menyenangkan dan semi fantasi. Finishing lapisan luar boneka menggunakan kain blacu yang diwarnai menggunakan pewarna kain, benang
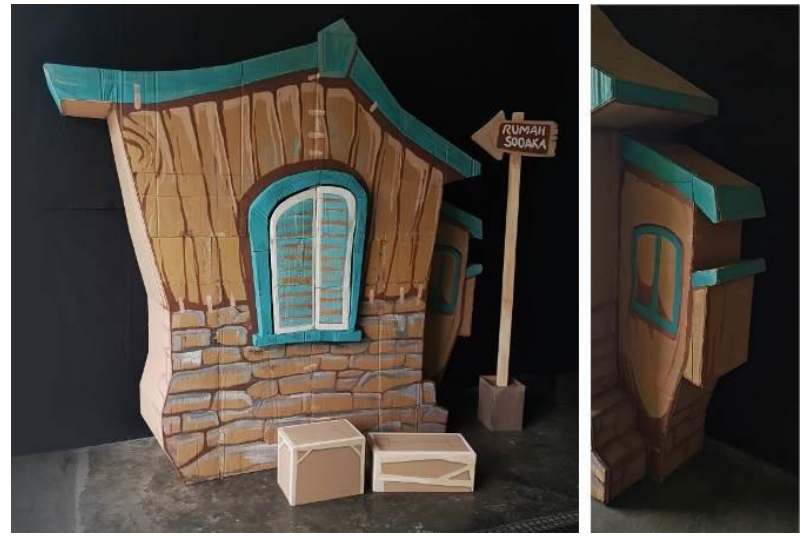

Gambar 11. Set Property Rumh Sooaka
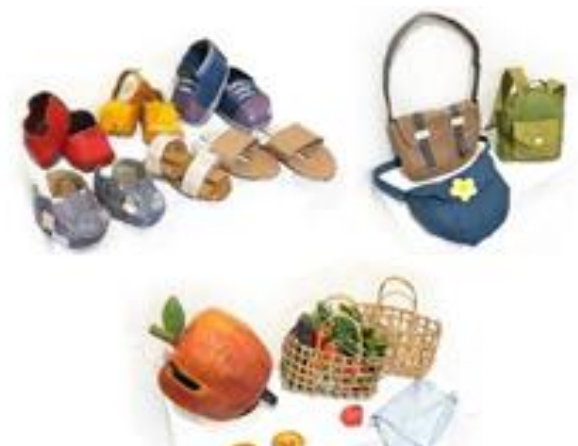

6

Gambar 12. Hand property

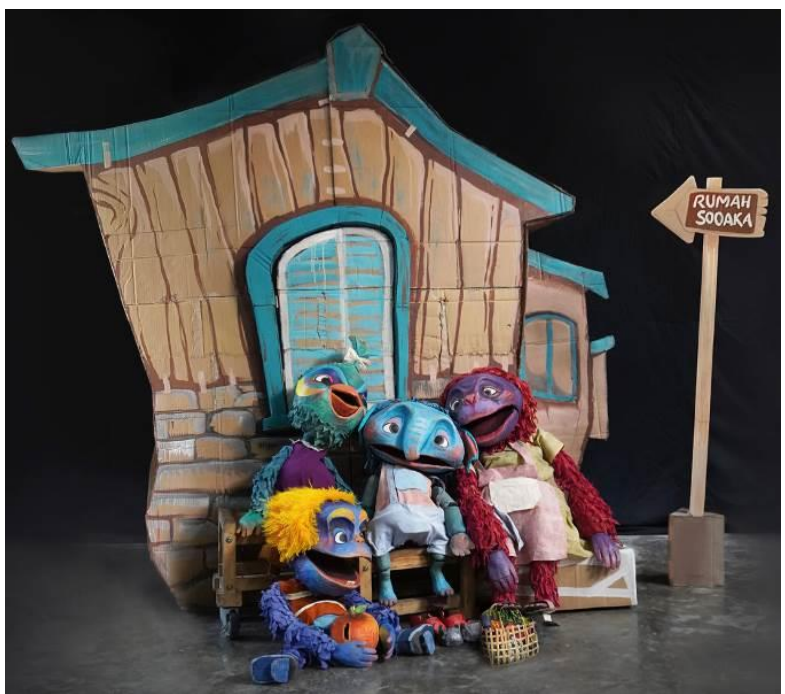

Gambar 13. Hasil Desain Perangkat Keseluruhan.

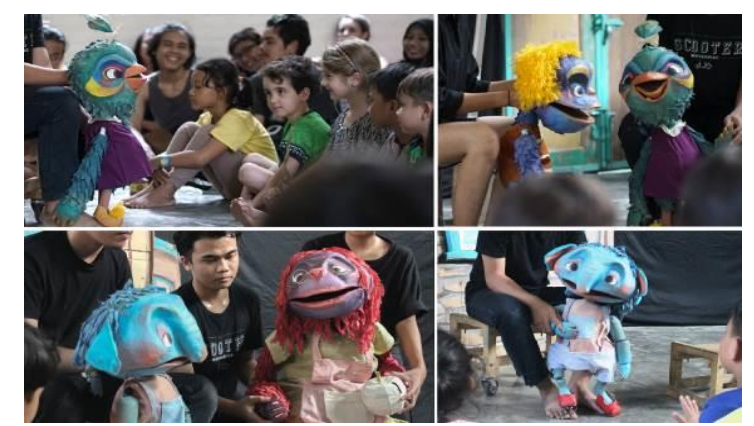

Gambar 14. Cuplikan Adegan Pementasan.

dan cat akrilik. Karakteristik material asli harus tetap dimunculkan untuk memberikan kesan hand made. 


\section{Desain environment}

Environment utama Tangkupet berada di Rumah Sooaka. Tempat ini merupakan bangunan panti asuhan yang di dalamnya terdiri dari asrama tinggal, taman belajar dan area bermain. "Sooaka" diambil dari kata "Suaka margasatwa" yang mana memiliki arti sebagai tempat penangkaran hewan endemik langka di habitat aslinya. Ide inilah yang diadaptasi sebagai rumah panti asuhan Sooaka, yang mana adalah panti asuhan sebagai tempat tinggal anak-anak hewan langka tersebut. Rumah ini yang akan menjadi setting latar utama dalam serial teater boneka Tangkupet. Bentuk bangunan dibuat dengan kesan bangunan yang sederhana dan sesuai ciri khas rumah-rumah masyarakat lokal seperti pada Gambar 10.

Gaya visual mengacu pada gaya stilasi dan rustic agar terkesan menyenangkan dan semi fantasi. Visual rumah ini lebih menonjolkan struktur atap yang miring. Bentuk ini banyak digunakan pada rumah-rumah yang berada di daerah iklim tropis karena berfungsi untuk mengalirkan air hujan dengan baik ke tanah dan tahan terhadap terpaan angin kencang. Rumah ini mengandung banyak unsur kayu dan batu bata kapur dengan warna natural yang berfungsi untuk memberikan kesan rumah yang sangat sederhana. Dalam pengaplikasian sebagai perangkat pertunjukan, Environment dibagi menjadi set properti dan hand property seperti pada Gambar 11

Set Props hanya tampak depan dan samping. Set Props sistem perakitan bongkar pasang (Knock-down). Set property ini dibuat dengan warna redup karena fungsinya adalah sebagai latar belakang, sehingga visibilitas terutama warnanya tidak boleh lebih menonjol dari pada warna-warna boneka karakternya. Meskipun terkesan monokrom, rumah ini tetap diberi aksen dengan warna identitas tangkupet, warna toska. Pemilihan material kardus sebagai lapisan terluar karena terispirasi dari kebiasaan anak-anak saat membuat prakarya menggunakan bahan bekas yang mudah ditemui dan diolah seperti kardus. Sehingga material ini diharapkan mampu menimbulkan kesan dekat dengan anakanak.

Hand property ini berguna sebagai properti tambahan antara lain adalah berbentuk tas sekolah; sepatu dan sandal; celengan apel dan koin; serbet; keranjang rotan dan sayuran seperti pada Gambar 12.

\section{Hasil Desain Keseluruhan}

Luaran dari perancangan ini berupa cerita dan perangkat pertunjukan yang ditampilkan melalui pementasan secara live performing kepada target audiens anak-anak dapat dilihat pada Gambar 13 - 14 .

\section{KESIMPULAN}

Pertunjukan Serial Teater Boneka Tangkupet secara keseluruhan dapat dijadikan sebagai media hiburan edukatif dalam bentuk pertunjukan live performing untuk anak-anak, di tengah kebiasaan anak-anak yang kecanduan gadget. Konsep teater boneka Tangkupet dinilai sangat menarik karena mampu menonjolkan visual dan verbal yang samasama kuatnya. Pertunjukan dengan bentuk semacam ini masih jarang ditemui di Indonesia, sehingga teater boneka ini memiliki peluang diminati anak-anak.

Selain itu, Setial teater Boneka Tangkupet ini juga sudah memiliki identitas tersendiri, mampu menampilkan spirit budaya lokal melalui pengaplikasian unsur identitas lokal Indonesia pada seluruh elemennya, seperti pada cerita, desain boneka karakter dan environment. Luaran perancangan ini berupa cerita serial yang terdiri dari 20 sinopsis cerita dengan tema slice of life tentang keseharian anak-anak hewan langka yang tinggal di rumah panti asuhan Sooaka. Masing-masing cerita terdapat pesan nilai pendidikan karakter. Salah satu episodenya yang berjudul "Sepatuku Juga Bagus" dengan nilai karakter kerja keras dan rajin menabung dibuat ke bentuk naskah pertunjukan dengan durasi pementasan 22 menit. Desain karakter yang dihasilkan sebanyak 10 karakter yang mengadaptasi satwa endemik langka Indonesia. Masing-masing karakter memiliki latar belakang sesuai dengan hewan-hewan tersebut yang dipadukan dengan sifat anak-anak pada umumnya. Boneka karakter berjumlah 4 dengan karakter sesuai dengan kebutuhan naskah episode pertama. Desain environment berupa satu set property berbentuk rumah perkampungan lokal dan hand property sebagai properti pendukung.

\section{DAFTAR PUSTAKA}

[1] D. Currell, Puppets and Puppet Theatre, Illustrate. Marlborough: Crowood Press, 1999

[2] A. Wikayanto, B. Grahita, and R. Darmawan, "Unsur-unsur Budaya Lokal dalam Karya Animasi Indonesia Periode Tahun 2014-2018," J. Rekam, vol. 15, no. 2, pp. 83-101, 2019.

[3] J. Taylor, Handspring Puppet Company. New York: David Krut Publishing, 2009.

[4] A. Wikayanto, "Representasi Budaya Dan Indentitas Nasional Pada Animasi Indonesia," in nternational Conference ARTESH 2018, 2018.

[5] G. Latshaw, The Complete Book of Puppetry (Dover Craft Books). New York: Dover Publications, Inc, 2012

[6] F. Glebas, Directing the Story: Professional Storytelling and Storyboarding Techniques for Live Action and Animation 1st Edition. Oxford, UK: Focal Press, 2008.

[7] A. Yonny, Drama: Panduan Bagi Pelajar. Yogyakarta, Indonesia: Suaka Media, 2014

[8] J. Sulianto, M. F. A. Untari, and F. Yulianti, "Media boneka tangan dalam metode bercerita untuk menanamkan karakter positif kepada siswa sekolah dasar," J. Pendidik., vol. 15, no. 2, pp. 94-104, 2014.

[9] I. B. Sutresna, I. W. Rasna, and N. W. S. Binawati, "Cerita Asing yang Digemari Anak SD: Sebuah Kajian Unsur Intrinsik," J. Ilmu Sos. dan Hum., vol. 1, no. 2, pp. 92-101, 2012.

[10] C. L. Burke and J. G. Copenhaver, "Animals as People in Children's Literature," Lang. Arts, vol. 81, no. 3, 2004.

[11] T. J. Jardim and P. Tshabalala, "Animals as character: Anthropomorphism as personality in animation," University of the Witwatersrand, 2013.

[12] B. Tillman, Creative Character Design. Waltham, Massachusetts: Focal Press, 2011.

[13] J. M. Gillette, Theatrical Design and Production: An Introduction to Scene Design and Construction, Lighting, Sound, Costume, and Makeup 7th Edition. New York: McGraw-Hill Education, 2012 